\title{
Prevalence of syphilis, neurosyphilis and associated factors in a cross-sectional analysis of HIV infected patients attending Bugando Medical Centre, Mwanza, Tanzania
}

\author{
Adeodatus Haule ${ }^{1 *}$, Betrand Msemwa ${ }^{2}$, Evarista Mgaya ${ }^{3}$, Peter Masikini ${ }^{1}$ and Samuel Kalluvya ${ }^{1}$
}

\begin{abstract}
Background: HIV-syphilis co-infection can enhance the rapid progression of early or late latent syphilis to neurosyphilis and can cause catastrophic neurological complications. In studies in Mwanza, syphilis affects 8\% of healthy outpatients and studies done in the 1990s have suggested that up to $23.5 \%$ of HIV-syphilis co-infected patients also have neurosyphilis.

Methodology: This was a cross sectional study in which adult HIV infected patients who were hospitalized or attending the outpatient Care and Treatment Clinic (CTC) were interviewed using a structured questionnaire and screened for syphilis using serum Treponema Pallidum Hemagglutination Assay (TPHA). Blood was also taken for CD4+ T cells and viral load. Those who were found to have syphilis underwent neurological examination for any neurologic deficit and were offered a lumbar puncture.

Results: The prevalence of syphilis in HIV infected patients was found to be $9.6 \%$. The majority of patients were female (72.5\%) and median age was 42 years [interquartile range, 32-50]. Most patients were on ART (99.4\%). In the study population of 1748 participants, 9.6\% were TPHA positive; the majority (89.2\%) reported not knowing their syphilis status and not previously been treated. One hundred and forty-one participants with syphilis had neurological examinations performed. Four of these had abnormal findings that necessitated a lumbar puncture. Neurosyphilis was confirmed in one patient (0.7\%).

Conclusion: The high prevalence of syphilis in HIV infected patients indicates that there is a need to increase efforts in targeting this population to reduce sexually transmitted infections. Screening for syphilis should be done for all HIV patients given the high prevalence of the infection and the risk that aggressive forms of neurosyphilis can occur despite recovery of CD4+ T cell counts in untreated syphilis.
\end{abstract}

Keywords: Human immunodeficiency virus, Syphilis, Neurosyphilis, Human immunodeficiency virus- Treponema pallidum co-infection

\footnotetext{
* Correspondence: hauleadeodatus@yahoo.com

'Department of Medicine, Catholic University of Health and Allied Sciences Bugando, Mwanza, Tanzania

Full list of author information is available at the end of the article
}

C C The Author(s). 2020 Open Access This article is licensed under a Creative Commons Attribution 4.0 International License, which permits use, sharing, adaptation, distribution and reproduction in any medium or format, as long as you give appropriate credit to the original author(s) and the source, provide a link to the Creative Commons licence, and indicate if changes were made. The images or other third party material in this article are included in the article's Creative Commons licence, unless indicated otherwise in a credit line to the material. If material is not included in the article's Creative Commons licence and your intended use is not permitted by statutory regulation or exceeds the permitted use, you will need to obtain permission directly from the copyright holder. To view a copy of this licence, visit http://creativecommons.org/licenses/by/4.0/. The Creative Commons Public Domain Dedication waiver (http://creativecommons.org/publicdomain/zero/1.0/) applies to the data made available in this article, unless otherwise stated in a credit line to the data. 


\section{Background}

In spite of effective preventive and treatment options, syphilis is still a global health problem causing high morbidity. It is estimated that about 10 million people worldwide are infected each year with a global prevalence of about $0.5 \%$ [1]. In sub-Saharan Africa, the burden has dropped from $6 \%$ to around $1 \%$ in the past 50 years $[1,2]$. In Tanzania the prevalence of syphilis ranges from 2.5 to $8 \%$ in antenatal clinics and community surveys, respectively [3, 4]. In sub-Saharan Africa heterosexuals are most highly affected [5].

Human Immunodeficiency Virus (HIV)-Treponema pallidum co-infection represents an important problem with serious clinical implications. The genital ulcers caused by primary syphilis infection facilitate acquisition of HIV. The genital ulcers are usually accompanied by inflammatory cells that express HIV co-receptors, facilitating establishment of initial HIV infection in the genital mucosa [5]. Additionally the presence of syphilis coinfection in HIV infected patients increases the HIV viral load [6]. HIV-Treponema pallidum co-infected individuals tend to develop neurosyphilis more frequently as compared to people with T.pallidum infection alone [5]. HIV infection has also been associated with syphilis treatment failure [7].

The prevalence of neurosyphilis in untreated early syphilis among HIV positive patients has been reported to be as high as $23.5 \%$ in Spain [8]. Likewise $24.6 \%$ of HIV positive patients were reported to have neurosyphilis in a study done in Canada and development of neurosyphilis was significantly associated with CD4 less than 500 cells/ $\mu$ l and uncontrolled viremia [9]. Little is known about the magnitude of the problem of HIVsyphilis in Africa [10]. Hence the study was designed to determine the prevalence of syphilis, neurosyphilis and associated factors among HIV positive patients at Bugando Medical Centre in Tanzania.

\section{Methods \\ Sample population, data collection, and laboratory testing and data analysis}

The study was conducted at Bugando Medical Centre's medical department. Bugando Medical Centre is one of four zonal hospitals in Tanzania; it serves a catchment population of about 15 million people with a bed capacity of about 900. The Bugando HIV outpatient clinic was started in 2004 and at present has more than 15,000 HIV-infected patients enrolled with over 5000 on antiretroviral therapy. The centre cares for all patients diagnosed from within the hospital and those sent from catchment facilities. All patients who are newly diagnosed with HIV are routinely screened for opportunistic infections and Hepatitis B and C. In the first 3 months of 2017 newly diagnosed HIV patients were screened for syphilis and 36/436(8.3\%) were Venereal Disease Research Laboratory (VDRL) positive. At the time of study screening for neurosyphilis was not done routinely.

This was an observational cross-sectional hospital based study. The study involved all HIV positive adult patients who were admitted to the Bugando Medical Centre medical wards and those who were seen at the CTC. All HIV positive patients who were 18 years and above and had tested positive for $T$. pallidum in the 3 months prior to study initiation or during the study period were included. All HIV negative patients were excluded.

The convenience sampling method was used; all HIV positive patients admitted to the hospital or being seen at the CTC over the 4 month period were approached to offer them the opportunity to participate in the study. All participants provided written consent.

A minimum sample size of 138 patients was calculated by means of the Kish Leslie formula using a predicted prevalence of neurosyphilis among HIV positive patients of $10 \%[8,9]$.

Participants were interviewed using a structured questionnaire which included age, sex, marital status, education, and a mental status examination. Five millilitres of blood were drawn by trained personnel into Ethylene Diamine Tetra Acetic Acid (EDTA) bottles and tested for Treponema pallidum antibodies by Treponema Pallidum Hemagglutination Assay (TPHA) as well as for CD4 count and viral load. Participants with positive results underwent a thorough neurological examination including cognitive assessment, fundoscopic examination and subjective audiometry (Weber and Rinne tests). These patients were also examined for sensory, motor, gait and balance deficits. Participants with neurologic abnormalities were offered a lumbar puncture by trained personnel. Neurosyphilis was defined according to the Centers For Disease Control and Prevention (CDC) criteria as serum treponemal test TPHA positive plus neurological features as well as CSF-VDRL positive and /or $20 \mathrm{WBC} /$ microlitre or more in CSF without other clear cause [11]. Patients discovered to have syphilis or neurosyphilis were referred to their attending physician who provided treatment as per CDC guidelines. The first line treatment for neurosyphilis was intravenous (IV) benzyl penicillin 18 to $24 \mathrm{MU}$ divided in 3 to $4 \mathrm{MU}$ every $4 \mathrm{~h}$ for 10 to 14 days; second line treatment was procaine penicillin G 2.4 MU daily with probenecid 500 mg four-hourly for 10 to 14 days. Patients were followed up for 30 days beginning from the day of treatment to assess clinical outcome after treatment $[11,12]$.

Data were collected using a coded questionnaire and entered into Microsoft Excel. Data was analysed using STATA version 13 (College Station, Texas). All continuous variables were summarized as medians with interquartile ranges, while categorical variables were summarized as 
Table 1 General characteristics of the 1748 HIV positive study participants

\begin{tabular}{|c|c|c|}
\hline Variable & Frequency & Percent or Median (IQR) \\
\hline \multicolumn{3}{|l|}{ Gender } \\
\hline Male & 496 & 28.4 \\
\hline Female & 1252 & 71.6 \\
\hline Age & 1748 & $42[34-50]$ \\
\hline $18-39$ & 729 & 41.7 \\
\hline $40-64$ & 966 & 55.3 \\
\hline $65-85$ & 53 & 3.0 \\
\hline \multicolumn{3}{|l|}{ Marital status } \\
\hline Single & 543 & 31.1 \\
\hline Married(monogamy) & 940 & 53.8 \\
\hline Polygamy & 258 & 14.8 \\
\hline Window & 7 & 0.4 \\
\hline \multicolumn{3}{|l|}{ Occupation } \\
\hline Vendor & 1114 & 63.7 \\
\hline Peasant & 338 & 19.3 \\
\hline Fisherman & 10 & 0.6 \\
\hline Employed & 211 & 12.1 \\
\hline House wife & 75 & 4.3 \\
\hline \multicolumn{3}{|l|}{ Residence } \\
\hline Mwanza city & 1552 & 88.8 \\
\hline Mwanza city & 196 & 11.2 \\
\hline \multicolumn{3}{|l|}{ Outside } \\
\hline \multicolumn{3}{|l|}{ Education } \\
\hline Illiterate & 126 & 7.2 \\
\hline primary & 1170 & 66.9 \\
\hline Secondary & 373 & 21.3 \\
\hline College & 60 & 3.4 \\
\hline University & 19 & 1.1 \\
\hline \multicolumn{3}{|c|}{ Reports being told to have syphilis } \\
\hline No & 1695 & 97.0 \\
\hline Yes & 53 & 3.0 \\
\hline \multicolumn{3}{|c|}{ Reports previously being treated for syphilis } \\
\hline No & 17 & 32.1 \\
\hline Yes & 36 & 67.9 \\
\hline \multicolumn{3}{|l|}{ Reports penicillin injection } \\
\hline One & 4 & 11.1 \\
\hline Three & 32 & 88.9 \\
\hline \multicolumn{3}{|l|}{ History of gental lesion $p$} \\
\hline No & 1698 & 97.1 \\
\hline Yes & 50 & 2.9 \\
\hline \multicolumn{3}{|l|}{ Number of lesion } \\
\hline One & 15 & 30 \\
\hline$>$ two & 35 & 70 \\
\hline
\end{tabular}

Duration of lesion 
Table 1 General characteristics of the 1748 HIV positive study participants (Continued)

\begin{tabular}{|c|c|c|}
\hline Variable & Frequency & Percent or Median (IQR) \\
\hline$<$ year & 29 & 58.0 \\
\hline 2-3 year & 11 & 22.0 \\
\hline 4-6 year & 4 & 8.0 \\
\hline$>6$ years & 6 & 12.0 \\
\hline \multicolumn{3}{|c|}{ Rashes on palm and sole } \\
\hline No & 1740 & 99.5 \\
\hline Yes & 8 & 0.5 \\
\hline \multicolumn{3}{|l|}{ Treatment for rashes } \\
\hline No & 3 & 37.5 \\
\hline Yes & 5 & 62.5 \\
\hline \multicolumn{3}{|l|}{ ART use } \\
\hline Not on ART & 1 & 0.1 \\
\hline ART use & 1747 & 99.9 \\
\hline \multicolumn{3}{|l|}{ Serum TPHA } \\
\hline Negative & 1581 & 90.5 \\
\hline Positive & 167 & 9.6 \\
\hline CD4 Cell/ul & 1748 & $526[362-706]$ \\
\hline$<350$ & 306 & 17.5 \\
\hline$>350$ & 1008 & 57.7 \\
\hline missing & 434 & 24.8 \\
\hline Viral load (copies/uL) & 1748 & 19 [19-20] \\
\hline$<50$ & 1333 & 76.3 \\
\hline 50-999 & 78 & 4.5 \\
\hline$>1000$ & 84 & 4.8 \\
\hline Missing & 253 & 14.5 \\
\hline
\end{tabular}

proportions or percentages using chi-squared tests. Univariable followed by multivariable logistic regression analyses were used to determine factors associated with syphilis. Any factor with a $p$-value of $<0.3$ on univariable logistic regression analysis was included in the multivariable model. A p-value of less than 0.05 was considered to be statistically significant in the final model.

Ethical clearance was obtained from the Catholic University of Heath and Allied Science / Bugando Medical Centre Joint Ethics and Review Committee with certificate number CREC/242/2017. Written informed consent was obtained from each patient or the patient's next of kin for those unable to consent for themselves because of illness or severe cognitive impairment. Results were communicated to the treating physician immediately and a copy of the results was placed in the patient's file.

\section{Results}

In this study, a total of 1748 participants were screened for syphilis and 167 (9.6\%) were found to be serum TPHA positive. More than half, 1008 (57\%) of the studied participants had enrolment CD4 counts of $>350$ cells/uL and 1333 (76.3\%) had viral loads of less than 50 copies /ml. Details of the 167 study participants who were TPHA positive are found in Table 1 . Females comprised a large number with positive serum TPHA (72.5\%) and the majority of those with TPHA positivity were aged 40-64 years (100/167, 59.9\%). The T.pallidum seropositive group was significantly older than the TPHA negative group as shown in Table 2. The TPHA positive group also had more monogamously married people and more people with only primary education. Vendors constituted the largest occupational group comprising $104(62.3 \%)$ among those who were T.pallidum seropositive.

In 167 participants, 18 (10.8\%) reported a previous history of syphilis and among them 12 (66.7\%) reported prior history of treatment with penicillin injections are found in Table 2. Of these, 10 (83.3\%) had 3 penicillin injection doses and $2(16.7 \%)$ received a single dose. Only 14 participants $(8.4 \%)$ reported a prior history of chancre while the majority $(10,71.4 \%)$ reported a single 
Table 2 Socio-demographic and reported clinical characteristics of 167 HIV-positive individuals who were serum T.pallidum seropositive compared to 1581 T.pallidum seronegative Participants

\begin{tabular}{|c|c|c|c|c|}
\hline \multirow[t]{2}{*}{ Variable } & \multicolumn{2}{|c|}{ TPHA Positive } & \multirow[t]{2}{*}{$x^{2}$} & \multirow{2}{*}{$\begin{array}{l}P \text { - } \\
\text { Value }\end{array}$} \\
\hline & YES N (\%) & NO N (\%) & & \\
\hline \multicolumn{5}{|l|}{ Gender } \\
\hline Male & $46(27.5)$ & $450(28.5)$ & 0.063 & 0.802 \\
\hline Female & $121(72.5)$ & $1131(71.5)$ & & \\
\hline \multicolumn{5}{|l|}{ Age } \\
\hline $18-39$ & $58(34.7)$ & $671(42.4)$ & 6.349 & 0.044 \\
\hline $40-64$ & $100(59.9)$ & $866(54.8)$ & & \\
\hline $65-84$ & $9(5.4)$ & $44(2.8)$ & & \\
\hline \multicolumn{5}{|l|}{ Marital status } \\
\hline Single & $38(22.8)$ & $505(31.9)$ & 15.73 & $<0.001$ \\
\hline Married(monogamy) & $94(56.3)$ & $846(53.3)$ & & \\
\hline Widow & $32(19.2)$ & $226(14.3)$ & & \\
\hline Polygamy & $3(1.8)$ & $4(0.25)$ & & \\
\hline \multicolumn{5}{|l|}{ Education } \\
\hline Illiterate & $29(17.4)$ & $97(6.1)$ & 34.53 & $<0.001$ \\
\hline Primary & $112(67.1)$ & 1058(66.9) & & \\
\hline Secondary & $21(12.5)$ & $352(22.3)$ & & \\
\hline College & $3(1.8)$ & $57(3.6)$ & & \\
\hline University & $2(1.2)$ & $17(1.1)$ & & \\
\hline \multicolumn{5}{|l|}{ Residence } \\
\hline Mwanza city & 148(88.6) & 1404(89) & 0.005 & 0.944 \\
\hline Outside Mwanza city & 19(11.4) & $177(11)$ & & \\
\hline \multicolumn{5}{|l|}{ Occupation } \\
\hline Vendor & $104(62.3)$ & 1010(63.9) & 19.28 & $<0.001$ \\
\hline Peasant & $44(26.4)$ & 294(18.6) & & \\
\hline Fisherman & $2(1.2)$ & $8(0.5)$ & & \\
\hline Employed & $6(4.0)$ & 205(13.0) & & \\
\hline House wife & $11(6.6)$ & $64(4.1)$ & & \\
\hline \multicolumn{5}{|c|}{ Reports previous history of syphilis } \\
\hline No & 149(89.2) & 1546(97.8) & 37.68 & $<0.001$ \\
\hline Yes & 18(10.8) & $35(2.2)$ & & \\
\hline \multicolumn{5}{|c|}{ Reported previous treated syphilis } \\
\hline No & $6(33.3)$ & $11(0.7)$ & 0.02 & 0.888 \\
\hline Yes & 12(66.7) & $24(1.5)$ & & \\
\hline \multicolumn{5}{|c|}{ Reports penicillin injection } \\
\hline One & 2(16.6) & $2(8.30)$ & 0.563 & 0.453 \\
\hline Three & 10(83.3) & 22(91.7) & & \\
\hline \multicolumn{5}{|l|}{ History of genital lesion } \\
\hline No & 153(91.6) & 1545(97.7) & 20.27 & $<0.001$ \\
\hline Yes & $14(8.4)$ & $36(2.3)$ & & \\
\hline \multicolumn{5}{|l|}{ Number of lesion } \\
\hline One & 10(71.4) & $5(13.9)$ & 15.89 & $<0.001$ \\
\hline Two or more & $4(28.6)$ & $31(89.1)$ & & \\
\hline
\end{tabular}


Table 2 Socio-demographic and reported clinical characteristics of 167 HIV-positive individuals who were serum T.pallidum seropositive compared to 1581 T.pallidum seronegative Participants (Continued)

\begin{tabular}{|c|c|c|c|c|}
\hline \multirow[t]{2}{*}{ Variable } & \multicolumn{2}{|c|}{ TPHA Positive } & \multirow[t]{2}{*}{$\mathrm{x}^{2}$} & \multirow{2}{*}{$\begin{array}{l}P \text { - } \\
\text { Value }\end{array}$} \\
\hline & YES N (\%) & NO N (\%) & & \\
\hline \multicolumn{5}{|l|}{ Duration of lesion } \\
\hline Less than a year & $9(64.3)$ & $20(55.6)$ & 0.536 & 0.911 \\
\hline Two to three year & $3(21.5)$ & $8(22.2)$ & & \\
\hline 4 to six year & $1(7.1)$ & $3(8.3)$ & & \\
\hline More than six year & $1(7.1)$ & $5(13.9)$ & & \\
\hline \multicolumn{5}{|c|}{ Rashes on palms and soles } \\
\hline No & 164(98.2) & 1576(99.6) & 7.264 & 0.007 \\
\hline Yes & $3(1.8)$ & $5(0.3)$ & & \\
\hline \multicolumn{5}{|l|}{ Treatment for rashes } \\
\hline No & $3(100.0)$ & $0(0)$ & 8 & 0.005 \\
\hline Yes & $0(0.0)$ & $5(100)$ & & \\
\hline \multicolumn{5}{|l|}{ ART use } \\
\hline No & $1(0.6)$ & $0(0)$ & 9.473 & 0.002 \\
\hline Yes & 166(99.4) & $1681(100)$ & & \\
\hline \multicolumn{5}{|l|}{ Duration of ART use } \\
\hline Less 6 month & $3(1.8)$ & 0 & 1400 & $<0.001$ \\
\hline 6 month to 2 years & 25(15.0) & 0 & & \\
\hline Above 2 yrs & $111(66.5)$ & 0 & & \\
\hline Missing & 28(16.8) & 1681 & & \\
\hline \multicolumn{5}{|l|}{ Viral load(copies/ml) } \\
\hline Less than 50 & 130(77.8) & 1203(79.1) & 1.424 & 0.7 \\
\hline 50-999 & $7(4.2)$ & $71(4.5)$ & & \\
\hline 1000 or more & $10(6.0)$ & $74(4.7)$ & & \\
\hline Missed viral load & $20(12.0)$ & $233(14.7)$ & & \\
\hline \multicolumn{5}{|l|}{ CD4 cell/uL } \\
\hline Less than 350 & $35(21.0)$ & $271(17.1)$ & 1.638 & 0.441 \\
\hline 350 and above & $94(56.3)$ & $914(57.8)$ & & \\
\hline Missing & $38(22.7)$ & $396(25.15)$ & & \\
\hline \multicolumn{5}{|l|}{ CSF WBC/UL } \\
\hline Less than or equal 5 & $4(100.0)$ & & & \\
\hline Greater 5 & $0(0.0)$ & & & \\
\hline \multicolumn{5}{|l|}{ CSF Treponema antibody } \\
\hline Negative & $3(75.0)$ & & & \\
\hline Positive & $1(25.0)$ & & & \\
\hline
\end{tabular}

genital lesion. In nine participants (64.3\%) the chancre had occurred in the past year. Only $3(1.8 \%)$ participants had reported painless rashes on the palms or soles and none of these received treatment. All except for one participant were on ART 166 (99.4\%).

Details of the 141 patients who underwent neurological examination are shown in Table 3. Most of the participants $(138,97.9 \%)$ had no cognitive impairment while one had mild and two had severe impairments.
Only two participants (1.5\%) had blurred vision and, after further examination, one was found to have a cataract in the left eye and the other had a corneal ulcer. Both of these patients were managed by the ophthalmologist accordingly. No features of syphilis of the eye were noted. Most of patients were on ART and the majority had been on ART for more than 2 years (111, $66.5 \%)$.s. A large number $(130,77.8 \%)$ of those who were seropositive for T.pallidum had a suppressed viral load 
Table 3 Clinical findings among 141 HIV positive patients who were seropositive for T.pallidum and returned for further evaluation Mwanza Tanzania

\begin{tabular}{lll}
\hline Variable & Frequency & Perce \\
\hline MMS & & 97.9 \\
$24-30$ & 138 & 0.7 \\
$18-23$ & 1 & 1.4 \\
$0-17$ & 2 & 0 \\
Neck pain noted on examination & & 0 \\
Yes & 0 & 100
\end{tabular}

Noted reduced vision

Yes

No

Seen with confusion

Yes

No

Had noted with fever

Yes

No

Gait

Normal

Abnormal

Bedbound

Sight loss right

Absent

Present

sight loss left

Absent

Present

Uveitis

Absent

Present

Argyll-Robertson pupil

Absent

Present

Hearing loss right

Absent

Present

Hearing loss left

Absent

Present

Type of hearing loss

No deficit

Sensorineural

Conductive

Romberg's sign

142

141

141

0

141
Percent

97.9

0.7

1.4

0

100

0.7

1.5

100.0 
Table 3 Clinical findings among 141 HIV positive patients who were seropositive for T.pallidum and returned for further evaluation Mwanza Tanzania (Continued)

\begin{tabular}{lll}
\hline Variable & Frequency & Percent \\
\hline Negative & 141 & 100.0 \\
Positive & 0 & - \\
Position sense & 141 & 100.0 \\
Normal & 0 & - \\
Abnormal & & 100.0 \\
Vibration sense & 141 & - \\
Normal & 0 & 100.0 \\
Abnormal & 0 & - \\
Reflexes & 141 & - \\
Normal & 0 & \\
Reduced & 0 & \\
Exaggerated & & \\
\hline
\end{tabular}

of less than 50 copies/ml and only a small number of participants $(10,6 \%)$ had a viral load of more than 1000 copies/uL. More than half of the participants had CD4+ T cells above 350 cells/uL (94, 56.3\%).

Two patients were noted to have confusion $(1.5 \%)$ of whom one had fever as well $(0.7 \%)$. Both of these were bedbound and their gait could not be assessed. No participant was noted to have sight loss, uveitis, or ArgyllRobertson pupils. Two of the participants were noted to have hearing loss. One had right-sided sensorineural hearing loss while all other neurological features were normal. The other had reduced cognition, thus, it was difficult to assess the type of hearing loss. The bed bound patients did not have Romberg or vibration sense tests done. All the other patients had negative Romberg's tests and a normal vibration sense. All had normal reflexes.

There were four participants who were seropositive for T. pallidum with neurological abnormalities who underwent lumbar puncture after counselling and consent as shown in Table 5. One patient was CSF-VDRL positive and had CSF-WBC $<5$ cells/uL. Three patients had negative CSF-VDRL and CSF-WBC $<5$ cells/uL. In the univariable logistic regression analysis, several factors were statistically significantly associated with seropositivity for T.pallidum including older age (Odds ratio (OR) 2.37 [95\% confidence interval (CI), 1.10-5.09], $p=$ 0.027 ), being widowed (OR 1.88 [1.50-3.90], $p=0.013$ ), polygamy (OR 9.97, [2.15-46.16], $p=0.003$ ), prior history of genital chancre (OR 3.93, [2.07-7.44], $p<0.001$ ), and previous history of syphilis (OR 5.34 [95\% CI, 2.959.65], $P<0.001$ ) details of the finding is found in Table 4. On multivariable logistic regression analysis, only polygamy (OR 8.51 [1.71-42.37], $p=0.009$ ) and previous history of syphilis (OR 3.5[1.75-7.01], $p<0.001$ ) remained independently associated with syphilis co-infection.
One patient among four had neurosyphilis confirmed with CSF-VDRL positive while CSF $-\mathrm{WBC}<5$. The other three patients did not meet the criteria of neurosyphilis in HIV patients according to CDC recommendations. Table 5 below shows the details of the CSF finding after the lumbar puncture in the four patients who underwent a lumbar puncture.

\section{Discussion}

In this study of HIV positive participants, $9.6 \%$ were seropositive for T.pallidum. The finding was similar to a prevalence rate of $10.0 \%$ reported in a study done in Uganda [13] and another in Ethiopia where 9.8\% out of the 306 HIV positive patients were found to be seropositive for T.pallidum [14]. The seroprevalence that we observed was lower than that found in Ghana $(14.8 \%$ of 284 HIV-infected participants) and higher than a study done in Rwanda in which $4.8 \%$ of 482 HIV infected participants were syphilis seropositive.

People who reported being married to one person were significantly more frequently seropositive for T.pallidum (56.3\% versus $53.5 \%$ in the TPHA negative). This finding is similar to study results from Uganda [13] and Ethiopia [14] and may be because of concurrency of partners. Specifically, Kenyon et al reported that male partner concurrency in which men had an average of five concurrent partners was significantly associated with a high prevalence of syphilis [15]. People who were TPHA positive were significantly more likely to have only a primary education perhaps suggesting that they may have a lower knowledge of preventive measures against sexually-transmitted infections. This finding was contrary to the study done in Ethiopia in which having a secondary education was associated with TPHA positivity. Employed persons were less likely to have seropositive T.pallidum in our study. Only $10 \%$ of the patients 
Table 4 Univariable and multivariable analysis for factors associated with syphilis co- infection

\begin{tabular}{|c|c|c|c|c|}
\hline \multirow[t]{2}{*}{ Variable } & \multicolumn{2}{|l|}{ Univariable } & \multicolumn{2}{|l|}{ Multivariable } \\
\hline & OR $(95 \% \mathrm{Cl})$ & $P$ Value & $\mathrm{OR}(95 \% \mathrm{Cl})$ & $P$ Value \\
\hline \multicolumn{5}{|l|}{ Sex } \\
\hline Male & 1 & & & \\
\hline Female & $1.04(0.73-1.50)$ & 0.802 & & \\
\hline \multicolumn{5}{|l|}{ Age } \\
\hline $18-39$ & 1 & & 1 & - \\
\hline $40-64$ & $1.34(0.95-1.87)$ & 0.094 & $1.13(0.78-1.63)$ & 0.514 \\
\hline $65-85$ & $2.37(1.10-5.09)$ & 0.027 & $1.34(0.57-3.13)$ & 0.502 \\
\hline \multicolumn{5}{|l|}{ Marital status } \\
\hline Single & 1 & & 1 & - \\
\hline Married & $1.48(1.00-2.29)$ & 0.052 & $1.42(0.94-2.14)$ & 0.091 \\
\hline Widow & $1.88(1.50-3.90)$ & 0.012 & $1.47(0.86-2.52)$ & 0.158 \\
\hline Polygamy & $9.97(2.15-46.16)$ & 0.003 & $8.51(1.71-42.37)$ & 0.009 \\
\hline \multicolumn{5}{|l|}{ Education } \\
\hline Illiterate & 1 & & 1 & - \\
\hline Primary & $0.35(0.22-0.56)$ & $<0.001$ & $0.38(0.23-0.61)$ & $<0.001$ \\
\hline Secondary & $0.2(0.19-0.36)$ & $<0.001$ & $0.26(0.14-0.50)$ & $<0.001$ \\
\hline College & $0.18(0.05-0.60)$ & 0.006 & $0.29(0.08-1.06)$ & 0.062 \\
\hline University & $0.39(0.86-1.80)$ & 0.230 & $0.77(0.16-3.67)$ & 0.739 \\
\hline \multicolumn{5}{|l|}{ Occupation } \\
\hline Vendor & 1 & & 1 & - \\
\hline Peasant & $1.45(1.00-2.17)$ & 0.051 & $1.15(0.77-1.72)$ & 0.489 \\
\hline Fisherman & $2.43(0.51-11.58)$ & 0.226 & $1.76(0.29-10.54)$ & 0.535 \\
\hline Employed & $0.28(0.12-0.66)$ & 0.003 & $0.33(0.14-0.78$ & 0.011 \\
\hline House wife & $1.16(0.85-3.26)$ & 0.134 & $1.57(0.79-3.13)$ & 0.202 \\
\hline \multicolumn{5}{|l|}{ Chancre } \\
\hline No & 1 & & 1 & - \\
\hline Yes & $3.93(2.07-7.44)$ & $<0.001$ & $2.1(0.96-4.58)$ & 0.063 \\
\hline \multicolumn{5}{|l|}{ Rashes } \\
\hline No & 1 & & 1 & - \\
\hline Yes & $5.76(1.37-24.34)$ & 0.017 & $2.02(0.41-9.92)$ & 0.388 \\
\hline \multicolumn{5}{|l|}{ Told syphilis } \\
\hline No & 1 & & 1 & - \\
\hline Yes & $5.34(2.95-9.65)$ & $<0.001$ & $3.5(1.75-7.01)$ & $<0.001$ \\
\hline \multicolumn{5}{|c|}{ Previously treated syphilis } \\
\hline No & 1 & & & \\
\hline Yes & $0.92(0.27-3.08)$ & 0.888 & & \\
\hline \multicolumn{5}{|c|}{ Viral load (copies/uL) } \\
\hline$<50$ & 1 & & & \\
\hline 50-999 & $0.91(0.41-2.02)$ & 0.822 & & \\
\hline 1000 or more & $1.25(0.63-2.48)$ & 0.522 & & \\
\hline Not tested & $0.79(0.49-1.30)$ & 0.358 & & \\
\hline
\end{tabular}

who were seropositive for T.pallidum reported a previous history of syphilis. Syphilis is not screened for routinely among people living with HIV and perhaps at times not thought to be an important problem. Similarly, high rates of undiagnosed syphilis have been reported in Ethiopia. For those who had syphilis, only two-thirds (66.7\%) received treatment. The majority received three intramuscular penicillin doses according to CDC recommendation as also reported by Katz and colleagues [16].

Most patients who were seropositive for T.pallidum had CD4+ T cells above 350 cells/uL (56.3\%) and viral load levels less than 50 copies/mL (77.8\%) contrary to our hypothesis that those with T.pallidum seropositivity would have low CD4+ T cell counts. We did not find an association between syphilis and CD4 counts or viral loads. This might be because most of the patients in our study were on ART and in a latent stage of syphilis. Our results contrast with the study in the US by Kate et al which reported that syphilis reduces CD4+ T cells and increases viral load [6], particularly in those with secondary syphilis on ART and those with syphilis not on ART. We also found that the majority of participants who were seropositive for T.pallidum reported no prior history of genital lesion (97.1\%), possibly due to the painless lesions of syphilis that might go unnoticed in primary stages. A study in Spain similarly found that few patients who were seropositive for T.pallidum reported a past genital lesion [8].

Among the 141 participants who were serum TPHA positive and returned to the clinic for neurological assessment, 3 participants had cognitive impairment. One of those with cognitive impairment also had hearing loss. The second patient had hearing loss alone with no other symptoms. The third patient had fever, headache, and altered mental status. The patients were also assessed for any sign of meningeal irritation but no one was positive. In addition, eye examinations failed to identify a patient with typical features of ophthalmic syphilis. Patients were also examined for gait, unilateral weakness, and sensory modalities; they were all found to be normal. This is in contrast with the study done in the US by Katz et al which found 12 patients with neurosyphilis, of whom 4 had eye problems, 3 had an altered mental status and 5 had unilateral weakness [16]. Of note, a major difference between the Tanzanian and the US study is that not all US patients were on ART, whereas all but one of the Tanzanian study patients were on ART.

Among the 141 screened by examination, only 4 (2.8\%) had neurological symptoms necessitating a lumbar puncture to assess for neurosyphilis. This was in accordance with expert guidelines recommending lumbar punctures only for those with neurological abnormalities but not for all seropositive for T.pallidum plus HIVpositive patients $[11,12,17]$. In our study, among the 4 
Table 5 Clinical Descriptions of Four seropositive for T.pallidum patients who had neurologic abnormalities and underwent lumbar puncture

\begin{tabular}{|c|c|c|c|c|}
\hline $\begin{array}{l}\text { Patient } \\
\text { number }\end{array}$ & 1 & 2 & 3 & 4 \\
\hline Gender & Male & Female & Female & Female \\
\hline $\begin{array}{l}\text { Age in } \\
\text { (years) }\end{array}$ & 50 & 65 & 57 & 30 \\
\hline ART use & Not on ART & yes & yes & yes \\
\hline $\begin{array}{l}\text { Duration of } \\
\text { ART }\end{array}$ & - & 4 months & 2 years & 7 year \\
\hline $\begin{array}{l}\text { Neurologic } \\
\text { features }\end{array}$ & $\begin{array}{l}\text { Headache } \\
\text { Confusion } \\
\text { fever }\end{array}$ & $\begin{array}{l}\text {-Disturbed } \\
\text { memory }\end{array}$ & $\begin{array}{l}\text { Confusion } \\
\text { Hearing loss left } \\
\text { Disturbed memory } \\
\text { and cognition }\end{array}$ & $\begin{array}{l}\text { Hearing loss right ear which is } \\
\text { sensorineural No ear discharge } \\
\text { Normal other system }\end{array}$ \\
\hline CD4+/uL & 412 & - & 219 & 270 \\
\hline $\begin{array}{l}\text { Viral load } \\
\text { (copies/UI) }\end{array}$ & Not tested & Not tested & 19 & 19 \\
\hline CSF finding & $\begin{array}{l}\text {-Positive VDRL } \\
\text {-WBC }<5 / \text { LL } \\
\text { Glucose low( } 2.99 \text { mmol) } \\
\text {-Normal protein } \\
\text {-Cryptococcal antigen negative(CRAG) } \\
\text {-Clear fluid with negative gram stain and culture } \\
\text {-Opening pressure extremely high }\end{array}$ & $\begin{array}{l}\text { Negative VDRL } \\
\text {-WBC }<5 / \text { UI } \\
\text {-Normal glucose } \\
\text {-Normal protein } \\
\text {-Negative CRAG } \\
\text {-Negative culture }\end{array}$ & $\begin{array}{l}\text { Negative VDRL } \\
\text { WBC }<5 \text { cell/UI } \\
\text { Normal glucose } \\
\text { Normal protein } \\
\text { Negative culture } \\
\text { Negative CRAG }\end{array}$ & $\begin{array}{l}\text {-Negative VDRL } \\
\text { WBC }<5 \text { cell/uL } \\
\text { Normal glucose } \\
\text { Normal protein } \\
\text { Negative culture }\end{array}$ \\
\hline Diagnosis & Neurosyphilis with meningoencephalitis & $\begin{array}{l}\text { Presumed HIV } \\
\text { Encephalopathy }\end{array}$ & $\begin{array}{l}\text { Presumed HIV } \\
\text { Encephalopathy }\end{array}$ & Hypoacusis due to other causes \\
\hline Outcome. & $\begin{array}{l}\text { Admitted to the ward and started on Ceftriaxone } 2 \mathrm{~g} \\
\text { IV BD. Died after three days in the course of } \\
\text { treatment in the ward. }\end{array}$ & $\begin{array}{l}\text { Alive, cognition } \\
\text { deficit improving } \\
\text { on ART. }\end{array}$ & $\begin{array}{l}\text { Discharged home } \\
\text { alive but later died } \\
\text { at home. }\end{array}$ & $\begin{array}{l}\text { Alive and hearing deficit has } \\
\text { improved }\end{array}$ \\
\hline
\end{tabular}

participants with syphilis who underwent a lumbar puncture, one was confirmed to have neurosyphilis. That person had no prior history of syphilis and was not on ART. The CD4+ T cell count was 412 cells/uL. The patient was treated with daily intravenous ceftriaxone as per the CDC guidelines but died after 3 days on the ward after a rapid neurologic deterioration. This patient might have suffered from the meningoencephalitic form of neurosyphilis which has a swift progression with a poor prognosis in HIV positive patients. This form of neurosyphilis was seen in one case study in a HIV-positive patient who presented with abnormal behaviour [18]. In HIV positive patients, even those with normal CD4+ T cell counts, immune cells may have altered function increasing the risk of syphilitic meningoencephalitis [19]. Likewise a study in the US found 16 neurosyphilis patients who were identified with only CSF-VDRL positivity among 50 patients with neurosyphilis [20]. By contrast, in the study done in Spain, all patients who had a diagnosis of neurosyphilis presented with mild headache, had no prior history of treatment, and improved after therapy [8]. Patients, who were negative for neurosyphilis, were all on ART and reported no history of prior treatment for syphilis. This may have occurred because ART use reduces the chances of having neurosyphilis to a level comparable to that of HIVuninfected people with syphilis [21].

In our study, we found a prevalence of neurosyphilis of only $0.7 \%$ for all who were examined for neurologic features. This prevalence was surprisingly low given the findings of other studies that have suggested the prevalence could be as high as $25 \%$. This low prevalence may be due either to ART use in most patients or possibly to having been previously treated with antibiotics, for a different indication, that have activity against Treponema pallidum. Our findings on neurosyphilis fit with a systemic review of neurosyphilis in Africa [22], which found only two patients with meningitis (3.3\%). Another study done in Brazil had shown the prevalence of neurosyphilis to be $1 \%$ among HIV positive patients with neurologic features [23]. In contrast, a study by Alverez et al showed that $23.5 \%$ T.pallidum seropositive patients who were not on ART had neurosyphilis [8]. Therefore, our study documents an important and encouraging finding that rates of neurosyphilis are lower in our setting than previously reported. This may be due to the expanding use of ART and also to the use of antibiotics, some of which may be excessive, but may serve inadvertently to treat T.pallidum seropositive patients and prevent neurosyphilis. 
Our study had some limitations. It was difficult to know if patients had been previously treated for syphilis with other agents that are active against syphilis like ceftriaxone or doxycycline because of the lack of electronic data keeping. In our study, we did not perform a lumbar puncture in patients without neurologic features and, hence, we may have missed asymptomatic neurosyphilis. We were not able to determine whether a patient may have had seroreversion of syphilis as the reagent used was only qualitative and usually stays positive for life. Risk factors for neurosyphilis could not be determined due to the very small number. HIV-positive patients with neurosyphilis may die rapidly and this crosssectional study would not have found those patients.

\section{Conclusion}

We found a high percentage of seropositivity for T.pallidum in HIV positive participants in which one out of ten people was affected yet a very low prevalence of neurosyphilis. This argues for the need for sexually transmitted infection (STI) screening especially syphilis with a specific focus on HIV positive patients. Factors associated with syphilis were having multiple partners and having a low level of education. We also observed a high rate of untreated syphilis among HIV-positive patients. Only $10.8 \%$ of HIV-positive patients who had syphilis were aware of their diagnosis which highlights the importance of prioritizing screening and treatment. We, therefore, recommend that screening for syphilis should be provided to all HIV positive individuals and that those with untreated syphilis should receive three doses of penicillin. For those with syphilis involving central nervous system manifestations, urgent treatment with benzyl penicillin or ceftriaxone according to the National Standard treatment guidelines or CDC recommendations is required. Screening and treating syphilis in all HIV positive patients should be routinely done as the disease can present as fulminant meningoencephalitis and, consequently, death. In HIV positive patients with neurological manifestations, neurosyphilis should be considered as one of the diagnoses. We recommend further studies being done among HIV positive patients with neurological manifestations who are admitted to the hospital to rule out neurosyphilis.

\section{Abbreviations \\ ART: Antiretroviral therapy; BMC: Bugando Medical Centre; CDC: Center for Disease Control; CD4: Cluster differention; CREC: CUHAS /BMC Joint Ethics and Review Committee; CSF: Cerebrospinal fluid; CTC: Care and treatment clinics; CUHAS: Catholic University of Health and Allied Sciences; HIV: Human immunodeficiency Virus; TPHA: Treponema pallidum Haemoglutination Assay; VDRL: Venereal disease research laboratory; WBC: White blood cell}

\section{Acknowledgements}

Special thanks go to Peramiho Mission Hospital and Weill Cornell Center for Global Health for financial assistance, staff members of Catholic University of
Health And Allied Sciences and Bugando Medical Centre as well as to the clients whom were willing to participate in the study.

\section{Authors' contributions}

AH was involved from the concept development to the manuscript writing $\mathrm{BM}$ was involved in processing collections and processing the samples. PM was involved in data processing and analysis. EM was involved in literature review pertain eye with syphilis and expert advice on examining participants with eye manifestation of syphilis. SK was involved in advising, reviewing and correcting from the concept paper development, to the research tools and improving the manuscript. The author(s) read and approved the final manuscript.

\section{Funding}

Not applicable.

\section{Availability of data and materials}

The datasets generated and/or analysed during the current study are available and can be accessed for further use in the

researchdata@springernature.com

\section{Ethics approval and consent to participate}

Ethical approval was obtained from the Catholic University of Health and Allied Science /Bugando Medical Centre Joint Ethics and Review Committee with certificate number CREC/242/201. The written consent form was obtained from all participants who were able to consent and for those who were not able because of the cognitive impairment the next of kin did it and ethical committee proved it.

\section{Consent for publication}

Not applicable.

\section{Competing interests}

Not applicable.

\section{Author details}

'Department of Medicine, Catholic University of Health and Allied Sciences Bugando, Mwanza, Tanzania. 'Laboratory, Catholic University of Health and Allied Sciences Bugando, Mwanza, Tanzania. ${ }^{3}$ Department of Ophthalmology, Bugando Medical Centre, Mwanza, Tanzania.

Received: 12 August 2019 Accepted: 26 November 2020

Published online: 04 December 2020

\section{References}

1. Newman L, Rowley J, Vander Hoorn S, Wijesooriya NS, Unemo M, Low N, et al. Global estimates of the prevalence and incidence of four curable sexually transmitted infections in 2012 based on systematic review and global reporting. PLoS One. 2015;10(12):1-17.

2. Kenyon CR, Osbak K, Tsoumanis A. The Global Epidemiology of Syphilis in the Past Century.A SystematicReview Based on Antenatal Syphilis Prevalence. PLOS Neg Trop Dis. 2016:10(5):2016:1-23.

3. Manyahi J, Jullu BS, Abuya MI, Juma J, Ndayongeje J, Kilama B, et al. Prevalence of HIV and syphilis infections among pregnant women attending antenatal clinics in Tanzania, 2011. BMC Public Health. 2015; 15:501.

4. Downs JA, Van Dam GJ, Changalucha JM, Corstjens PLAM, Peck RN, De Dood CJ, et al. Association of schistosomiasis and HIV infection in Tanzania. Am J Trop Med Hyg. 2012:87(5):868-73.

5. Funnye AS, Akhtar AJ, Uk DV. Syphilis and human immunodeficiency virus co-infection. J Natl Med Assoc. 2003;95:363-82.

6. Buchacz K, Patel P, Taylor M, Kerndt PR, Byers RH, Holmberg SD, et al. Syphilis increases HIV viral load and decreases CD4 cell counts in HIVinfected patients with new syphilis infections. AIDS. 2004;20(2):305-6.

7. Jinno S, Anker B, Kaur P, Bristow CC, Klausner JD. Predictors of serological failure after treatment in HIV-infected patients with early syphilis in the emerging era of universal antiretroviral therapy use. BMC Infect Dis. 2013;13(1):605

8. Alvarez M, Miralles C, Ocampo A, De Fuente-aguado J, Arguelles BS. Neurosyphilis in HIV-infected Patients. Eur J Clin Micrbiol Inf Dis. 1995; 14(10):864-9. 
9. Dumaresq J, Langevin S, Gagnon S, Serhir B, Deligne B, Tremblay C. Clinical Prediction and Diagnosis of Neurosyphilis in HIV-Infected Patients with Early Syphilis. JCM. 2013;51(12):4060-6.

10. NACP. National guidelines for the management of HIV and AIDS. 6th ed; 2017.

11. Kimberly A, Workowski BGA. Sexually Transmitted Diseases Treatment Guidelines, Morbidity and Mortality Weekly Report (MMWR), vol. 64; 2015. p. $1-137$.

12. Janier M, Hegyi V, Dupin N, Unemo M, Tiplica GS, Poto M. 2014 European guideline on the Management of Syphilis. JEADV. 2014;28:1581-93.

13. Mboowa G, Inda DA. Seroprevalence of syphilis among human immunodeficiency virus positive individuals attending immune suppressed syndrome clinic at international hospital Kampala, Uganda. Int STD Res Rev. 2015;3(3):84-90

14. Eticha BT, Sisay Z, Alemayehu A, Shimelis T. Seroprevalence of syphilis among HIV-infected individuals in Addis Ababa, Ethiopia: a hospital-based cross-sectional study. BMJ Open. 2013;3(4):e002566.

15. Kenyon CR, Osbak K. The Prevalence of Syphilis Is Associated with the Prevalence of Male Point-Concurrency : An Ecological Analysis. WJA. 2015;5:131-9.

16. Katz DA. Neurosyphilis in acquired immunodeficiency syndrome. Arch Neurol. 1989;46:895-8.

17. Kingston M, French P, Higgins S, McQuillan O, Sukthankar A, Stott C, et al. UK national guidelines on the management of syphilis 2015. Int J STD AIDS. 2016;27(6):421-46.

18. Singh MN. Early onset syphilitic Meningoencephalitis presenting as abnormal behaviour in a case of HIV infection. MJAFI. 2003;59:351-2.

19. Mark J. Syphilitic meningitis in a man with Seropositivity for human immunodeficiency virus infection and Normal numbers of CD4 T lymphocytes. Arch Intern Med. 2015;8103:6-8.

20. Marra CM, Maxwell CL, Smith SL, Lukehart SA, Rompalo AM, Eaton M, et al. Cerebrospinal Fluid Abnormalities in Patients with Syphilis : Association with Clinical and Laboratory Features. JID. 2004;2499:369-76.

21. Hall CS, Klausner JD, Bolan GA. Managing syphilis in the HIV-infected patient. Curr Infect Dis Rep. 2004;6(1):72-82.

22. Marks M, Jarvis JN, Howlett W, Mabey DCW. Neurosyphilis in Africa : a systematic review. PLOS Neglt Trop Dis. 2017;11(8):1-14.

23. De Oliveira JF, Greco DB, Oliveira GC, Christo PP, Drew M, Guimarães C, et al. Neurological disease in HIV-infected patients in the era of highly active antiretroviral treatment. Rev Soc Bras Med Trop. 2006;39(2):146-51.

\section{Publisher's Note}

Springer Nature remains neutral with regard to jurisdictional claims in published maps and institutional affiliations.

Ready to submit your research? Choose BMC and benefit from:

- fast, convenient online submission

- thorough peer review by experienced researchers in your field

- rapid publication on acceptance

- support for research data, including large and complex data types

- gold Open Access which fosters wider collaboration and increased citations

- maximum visibility for your research: over $100 \mathrm{M}$ website views per year

At $\mathrm{BMC}$, research is always in progress.

Learn more biomedcentral.com/submissions 